\title{
PLANNING AND APPLICATION OF METHODS IN DIFFERENTIATED INSTRUCTION AND INDIVIDUAL APPROACH TO PUPILS WITH DIFFICULTIES IN PRIMARY SCHOOL
}

\author{
Jasna Kudek Mirošević \\ University of Zagreb, Croatia \\ Mirjana Radetić-Paić \\ Juraj Dobrila University of Pula, Croatia
}

\begin{abstract}
In an inclusive school teachers are expected to take responsibility for planning the teaching process in which they will apply adequate support (Ahon Adaka, 2013; Tomlinson, 2015). The aim of this research is to determine certain specificities of teachers' differentiated instruction in their teaching and planning of individualised methods for the successful conduction of activities with pupils with difficulties in lower and higher grades of primary school. The set hypothesis states that there is a statistically significant difference between class teachers and subject teachers of primary schools of the Republic of Croatia $(N=410)$ in the estimation of their own planning and application of methods in differentiated instruction and individualised approach to pupils with difficulties. The nonparametric Mann-Whitney $U$ test was used to test the differences between teachers groups. The results showed that class teachers applied methods relating to pupils' more successful inclusion in activities and supported their individuality by applying individualised teaching aids more than subject teachers. Such results indicate that differentiated and individualised teaching methods which are most adequate for a certain pupil and which will support their self-activity during primary education are still insufficiently present, even more in higher grades of primary school.
\end{abstract}

Keywords: differentiation of instruction, individualised approach, methods, pupils with difficulties, teachers.

\section{Introduction}

Modern methods and educational technologies, which began to be used more and more in education at the beginning of the 21st century, have stimulated the growing need for differentiated teaching and individualized approach. Differentiated teaching is a pedagogical-methodical-didactic approach that has often emphasized the importance of teachers in meeting the different learning needs of pupils for the last three decades. According to Bondie, Dahnke, \& Zusho (2019) differentiated teaching refers to the adaptation of content (what is learned), 
process (how learning is structured), the final product, i.e. results (how learning is valued) and the physical learning environment, and such planning of differentiated teaching depends on the teacher's perception of the pupils' readiness to learn, his or her learning profile, and interests (Tomlinson \& Allan, 2000; Tomlinson, 2000; 2001). This definition was used to justify different approaches in teaching to meet the educational needs of pupils (Jenkins, Schiller, Blackorby, Thayer, \& Tilly, 2013) and their active participation in various activities in which they participate according to individual interests, including adjusting working hours and tasks appropriate to the abilities and capabilities of pupils (Grimes \& Stevens, 2009). Similar to differentiation, an individualized approach and learning is teaching that is based on the individual educational needs of pupils for learning. Individualization, however, focuses more on the time and pace of learning and teaching. Although technical differentiation and individualization are different concepts, they are part of the same strategy in the education system.

Pupils with difficulties have different and changeable needs and form a heterogeneous group in an inclusive school. Their educational needs relate to their developmental characteristics, personal experience, previously acquired competencies, habits, interests, social and cultural environment. Although teachers understand that not all pupils are the same and that their needs are diverse, there are still insufficient teachers acknowledging these differences in their classrooms (Subban, 2006; Van Casteren, Bendig-Jacobs, WartenberghCras, Van Essen, \& Kurver, 2017, according to Smale-Jacobse, Meijer, HelmsLorenz, \& Maulana, 2019).

Although differentiated teaching and individualized approach are often the focus of theoretical and practical considerations in research, not much research has been conducted about their benefits within empirical outcomes for improving pupil achievement in an inclusive school (Smale-Jacobse et al., 2019). In addition, schools today have classes with an average of 25 pupils, and subject teachers work in several such classes a day, so it is often difficult for them to provide individualized support to all pupils who need it. Therefore, one of the main challenges in education today is the planning of individualized support, and it is often difficult for teachers to plan and implement content and activities for each pupil at an appropriate level of learning, while teaching has to meet state standards of the education system. Some results from different countries indicate that teachers rarely adapt their teaching methods to the individual capabilities and abilities of pupils (Schleicher, 2016).

All of the above, for the benefit of each pupil, and also in the context of the aim of this research and hypothesis, emphasizes the fact that the process of differentiation cannot be improvised by the teacher during the learning process, but must be first systematically planned. The same applies to the planning of an 
individual approach, i.e. the application of those methods, tools and didactic materials that support the special educational needs of a particular student.

\section{Aim and Hypothesis}

The aim of this research is to determine certain specificities of teachers' differentiated instruction in their teaching and planning of individualised methods for the successful conduction of activities with pupils with difficulties in lower and higher grades of primary school.

In line with the above, it was hypothesized that there is a statistically significant difference between class teachers and subject teachers of primary school in the estimation of their own planning and application of methods for the successful conduction of activities in differentiated instruction and individualised approach to pupils with difficulties.

\section{Literature Review}

Today's contemporary schools are inclusive and follow educational policies aimed at respecting diversity, children's rights and involving pupils of culturally and linguistically diverse backgrounds and pupils with difficulties (Rock, Gregg, Ellis, \& Gable, 2008; Tomlinson, 2015 according to Smale-Jacobse et al., 2019). Although the concept of differentiated teaching is quite familiar, it is difficult for teachers to understand how differentiated teaching should be conducted in their classrooms (Van Casteren et al., 2017). In an inclusive school teachers are expected to take responsibility for planning the teaching process in which they will apply adequate differentiated and individualised forms of support.

While in some inclusive schools the traditional classroom is still present without any changes in teaching methods, resources and materials (BuliHolmberg, 2008) and teachers self-assess with insufficient planning and application of individualized methods, inclusive education is a challenge for teachers who have to teach and plan classes that make a combination of support for pupils with diverse needs and pupils with difficulties in classrooms. The best teaching practice in an inclusive classroom should reflect effective teacher-pupil interaction, which for pupils with difficulties means appropriate support from teachers with competencies that successfully meet the needs of pupils with difficulties (Buli-Holmberg \& Jeyaprathaban, 2016).

Teachers also need to plan aims, assessment and strategies to meet a range of developmental and educational needs of pupils with difficulties present in today's classrooms (Conderman \& Johnston-Rodriguez, 2009). Given that differentiated teaching starts from the fact that not all pupils are equal and therefore not all pupils learn in the same way, an individualized approach to 
teaching is crucial in planning lessons to respond to individual differences between pupils in classrooms (Tomlinson, 2001; 2004). Therefore, differentiated teaching requires teachers to be flexible in their teaching approaches and flexible in adapting the curriculum, rather than expecting pupils to adapt to the curriculum. Developing a wider range of teaching methods can not only help meet the needs of pupils with difficulties, but can help more pupils learn problem-solving concepts and give teachers the opportunity to self-evaluate (Thousand, Villa, \& Nevin, 2007).

\section{Research Methodology \\ General Characteristics of Research}

According to the modern, holistic approach, the success of pupils with difficulties depends on the type and amount of support provided to them in school and life. It follows that pupils with difficulties can be successful in regular schooling if they are provided with appropriate support, i.e. differentiation is carried out and the approach in the teaching process and schooling conditions is individualized.

In the Republic of Croatia, working conditions at school with all pupils, including pupils with difficulties are regulated by the State Pedagogical Standard. However, some research suggests that working in an inclusive classroom, where all pupils feel accepted, requires expanding traditional teaching practices, especially if the provision of individualized educational support to pupils with difficulties grows negatively in the upper grades, i.e. where the educational content is most extensive and the most demanding in terms of curriculum (Kudek Mirošević \& Bukvić, 2017). As a result, teachers who are willing to teach according to different learning styles of pupils to enable each student to actively participate in activities are needed (Obiakor, Harris, Mutua, Rotatori, \& Algozzine, 2012) such as the use of simple tools, such as manipulative materials and multi-sensory means, giving instructions and feedback, which encourages the development of different areas of learning for pupils with difficulties.

\section{Instrument, Data Collection and Processing Procedure}

For the purposes of the research, a Questionnaire for teachers on the planning and application of teaching methods was constructed (internal consistency Cronbach $\alpha=.819$, construct validity was quantified with Pearson correlation coefficient $r$, and total score is higher than the table value at the significance level of $\mathrm{p}=.05$ ). The research was held in 2018. Respondents filled out the questionnaire in physical presence in their schools following previous instructions from the researcher. The research was anonymous and conducted on a voluntary basis, 
respecting the ethical aspects of the research and informing all participants about the purpose and aim of the research, as well as the confidentiality of data obtained by the research.

The questionnaire consists of two parts; the first part refers to participants' gender, work with regard to lower or higher grades of primary school teaching, age and work experience, whereas the second part in this paper includes nine statements related to the planning and application of methods in teachers' work with pupils with difficulties (Table 1 and Table 3).

Teachers on a four-point Likert-type scale (daily-1, weekly-2, monthly-3, rarely-4) assessed how often they differentiated teaching and individualized the approach through the application of certain methods in teaching pupils with difficulties. The basic descriptive parameters were calculated on the obtained results and Mann-Whitney $U$ test was used. The data obtained from the research were processed by the licensed statistical package SPSS-23.

\section{Results and Discussion Participants}

As many as 410 teachers (89.2\% female and 10.8\% male) from primary schools in the Republic of Croatia participated in this research. Of the total number of teachers, 237 (57.8\%) were lower grade teachers and 173 (42.2\%) were higher grade teachers. With regard to age, most participants (32\%) were between the ages of 41 and 50 and between the ages of 31 and 40 (29.3\%). As many as $18.8 \%$ were between the ages of 51 and 60 are $18.8 \%, 14.9 \%$ were under the age of 30 years, while $5.0 \%$ of them were over the age of 60 . The least number of participants (13.1\%) have more than 30 years of work experience, followed by those who have up to 10 years of work experience (15.9\%) and those who have up to 5 years of work experience (20.0\%). Most participants have a work experience of 11 to 20 years (27.6\%) and of 21 to 30 years (23.4\%).

The basic descriptive values of the scale are shown in Table 1.

Table 1 Descriptive Values

\begin{tabular}{|l|c|c|c|c|c|c|c|c|}
\hline \multirow{2}{*}{ Items } & Range & Min. & Max. & \multicolumn{2}{|c|}{ Mean } & $\begin{array}{c}\text { Std. } \\
\text { deviation }\end{array}$ & Variance & K-S \\
\cline { 2 - 9 } & Stat. & Stat. & Stat. & Stat. & $\begin{array}{c}\text { Std. } \\
\text { Error }\end{array}$ & Stat. & Stat. & $\mathrm{p}$ \\
\hline $\begin{array}{l}\text { 1-changing the } \\
\text { classroom seating } \\
\text { arrangement depending } \\
\text { on the educational } \\
\text { needs of the pupils }\end{array}$ & 3 & 1 & 4 & 3.00 & .048 & .961 & .924 & .000 \\
\hline
\end{tabular}


Kudek Mirošević \& Radetić-Paić, 2021. Planning and Application of Methods in Differentiated Instruction and Individual Approach to Pupils with Difficulties in Primary School

\begin{tabular}{|l|c|c|c|c|c|c|c|c|}
\hline $\begin{array}{l}\text { 2-individualization of } \\
\text { verbal instructions and } \\
\text { teaching contents }\end{array}$ & 3 & 1 & 4 & 1.42 & .035 & .695 & .484 & .000 \\
\hline $\begin{array}{l}\text { 3-realization of planned } \\
\text { individualized curricula } \\
\text { and activities }\end{array}$ & 3 & 1 & 4 & 2.06 & .042 & .846 & .716 & .000 \\
\hline $\begin{array}{l}\text { 4-providing auxiliary } \\
\text { materials such as } \\
\text { individually made } \\
\text { board plan, abbreviated } \\
\text { and simplified texts, } \\
\text { learning questions, etc. }\end{array}$ & 3 & 1 & 4 & 1.64 & .040 & .807 & .651 & .000 \\
\hline $\begin{array}{l}\text { 5-use of teaching aids } \\
\text { such as concrete, } \\
\text { pictorial or graphic } \\
\text { representations, } \\
\text { schemes }\end{array}$ & 3 & 1 & 4 & 1.64 & .039 & .778 & .606 & .000 \\
\hline $\begin{array}{l}\text { 6-reducing task } \\
\text { difficulty }\end{array}$ & 3 & 1 & 4 & 1.38 & .032 & .646 & .417 & .000 \\
\hline 7-shortening tasks & 3 & 1 & 4 & 1.40 & .033 & .661 & .437 & .000 \\
\hline $\begin{array}{l}\text { 8-providing additional } \\
\text { time to solve tasks }\end{array}$ & 3 & 1 & 4 & 1.30 & .030 & .594 & .353 & .000 \\
\hline $\begin{array}{l}\text { 9-adjust text structure } \\
\text { (font, higher spacing, } \\
\text { more answer space, } \\
\text { etc.) }\end{array}$ & 3 & 1 & 4 & 1.96 & .051 & 1.007 & 1.014 & .000 \\
\hline
\end{tabular}

Regarding descriptive values for all participants, the results in Table 1, show that teachers in primary schools generally relatively rarely differentiate teaching and individualize the approach through the application of certain methods in teaching pupils with difficulties. They individualize the rarest with regard to the adaptation of space by organizing the seating arrangement of pupils depending on the educational needs of pupils and they do not implement individualized curricula and activities as planned. They adapt the text relatively rarely in the presentation of the content for the adoption of educational outcomes and use less auxiliary materials and other adaptations in the ways of presenting the visual content of learning. On the other hand, they individualize verbal instructions more often, in terms of understanding instructions in relation to content determinants, as well as shortening tasks, i.e. reducing tasks of equal difficulty. Teachers adapt the ways of setting requirements in terms of planning appropriate work time to solve tasks the most often, i.e. prolong or shorten the time needed by the pupil taking into account his or her perceptual, cognitive, sensory, and motor skills to carry out planned activities. Teachers also often select appropriate tasks according to their number and complexity. Namely, differentiated teaching presupposes individualized teaching methods and materials that correspond to the individual 
educational needs of pupils with learning difficulties and other different learning needs (Scruggs, Mastropieri, \& Marshak, 2012). In this context, these results point to the need to strengthen the professional competencies of teachers to provide more often differentiated support and modern teaching to pupils with difficulties in an education system that aims at a stimulating inclusive environment.

Since the Kolmogorov - Smirnov (K-S) test showed that all items significantly deviated from the normal distribution, the significance of differences on the basis groups were tested by a non-parametric statistical method, i.e., the Mann-Whitney U test.

First of all, the Mann-Whitney $U$ test is at the level of statistical significance (Table 2). This means that there is a statistically significant difference $(\mathrm{p}<.05)$ between class teachers and subject teachers in assessing all items i.e. frequency of their planning and application of observed methods, which confirms the hypothesis.

Table 2 Differences between Class Teachers and Subject Teachers of Primary School Shown by Mann-Whitney $U$ test

\begin{tabular}{|l|c|c|c|c|c|}
\hline Items & I1 & I2 & I3 & I4 & I5 \\
\hline Mann-Whitney U & 13231.500 & 14656.500 & 15308.000 & 12906.500 & 13859.000 \\
\hline Wilcoxon W & 39337.500 & 40991.500 & 41414.000 & 39241.500 & 40424.000 \\
\hline Z & -5.544 & -5.377 & -3.986 & -6.563 & -5.690 \\
\hline $\begin{array}{l}\text { Asymp. Sig. (2- } \\
\text { tailed) }\end{array}$ & .000 & .000 & .000 & .000 & .000 \\
\hline
\end{tabular}

\begin{tabular}{|l|c|c|c|c|}
\hline Items & I6 & I7 & I8 & I9 \\
\hline Mann-Whitney U & 15507.500 & 15862.500 & 15297.000 & 16722.500 \\
\hline Wilcoxon W & 41613.500 & 42427.500 & 41632.000 & 43287.500 \\
\hline Z & -4.155 & -3.538 & -4.657 & -2.133 \\
\hline $\begin{array}{l}\text { Asymp. Sig. (2- } \\
\text { tailed) }\end{array}$ & .000 & .000 & .000 & .033 \\
\hline
\end{tabular}


Kudek Mirošević \& Radetić-Paić, 2021. Planning and Application of Methods in Differentiated Instruction and Individual Approach to Pupils with Difficulties in Primary School

Table 3 Result of Mean Rank and Sum of Rank

\begin{tabular}{|l|c|c|c|}
\hline \multicolumn{1}{|c|}{$\begin{array}{c}\text { Items } \\
\text { For pupils with difficulties: How often you... }\end{array}$} & $\begin{array}{c}\text { Teachers of } \\
\text { primary school }\end{array}$ & $\begin{array}{c}\text { Mean } \\
\text { Rank }\end{array}$ & $\begin{array}{c}\text { Sum of } \\
\text { Ranks }\end{array}$ \\
\hline \multirow{2}{*}{$\begin{array}{l}\text { I1- change the seating arrangement in the classroom } \\
\text { depending on the educational needs of the pupils }\end{array}$} & lower grades & 172.53 & 39337.50 \\
\cline { 2 - 4 } & higher grades & $\mathbf{2 3 3 . 7 4}$ & 39268.50 \\
\hline \multirow{2}{*}{$\begin{array}{l}\text { I2- individualize verbal instructions and teaching } \\
\text { content }\end{array}$} & lower grades & 179.00 & 40991.50 \\
\cline { 2 - 4 } & higher grades & $\mathbf{2 3 0 . 2 9}$ & 39609.50 \\
\hline \multirow{2}{*}{$\begin{array}{l}\text { I3- manage to realize the planned individualized } \\
\text { curricula and activities }\end{array}$} & lower grades & 181.64 & 41414.00 \\
\cline { 2 - 4 } $\begin{array}{l}\text { I4- provide supporting materials such as an } \\
\text { individually designed board plan, abbreviated and } \\
\text { simplified texts, learning questions, etc. }\end{array}$ & higher grades & $\mathbf{2 2 5 . 5 0}$ & 38786.00 \\
\hline \multirow{2}{*}{$\begin{array}{l}\text { I5- use teaching aids such as concrete, pictorial or } \\
\text { graphic representations, diagrams, etc. }\end{array}$} & lower grades & 171.36 & 39241.50 \\
\hline i6- reduce the difficulty of tasks & lower grades & 175.76 & 40424.00 \\
\cline { 2 - 4 } & higher grades & $\mathbf{2 3 5 . 9 2}$ & 40579.00 \\
\hline \multirow{2}{*}{ I7- shorten tasks } & lower grades & 182.52 & 41613.50 \\
\cline { 2 - 4 } & higher grades & $\mathbf{2 2 1 . 2 4}$ & 37389.50 \\
\hline I8- provide extra time to solve tasks & lower grades & 184.47 & 42427.50 \\
\cline { 2 - 4 } & higher grades & $\mathbf{2 1 7 . 9 4}$ & 36178.50 \\
\hline \multirow{2}{*}{$\begin{array}{l}\text { I9- adjust text structure (font, higher spacing, more } \\
\text { answer space, etc.) }\end{array}$} & lower grades & 181.80 & 41632.00 \\
\cline { 2 - 4 } & higher grades & $\mathbf{2 2 2 . 4 5}$ & 37371.00 \\
\cline { 2 - 4 } & lower grades & 188.21 & 43287.50 \\
\hline \multirow{2}{*}{ higher grades } & $\mathbf{2 1 1 . 6 5}$ & 34922.50 \\
\hline
\end{tabular}

Further, Table 3 shows the mean ranks and sum of ranks, which are expected to differ by the observed groups, and they show how the group assessments differ in observed methods. Given the direction of differences and the prevalence of items (higher rank is a less common method used by teachers), the results show that subject teachers self-assess that less than class teachers self-assess their planning and application of methods for the successful implementation of activities in differentiated teaching and individualized approach to pupils with difficulties, which indicates the need to strengthen the professional competencies of teachers to provide support and modern teaching of pupils with difficulties, especially teachers of higher grades. The same results were shown by the research of (Kudek Mirošević \& Bukvić, 2017) in the sense that class teachers provide individualized educational support to pupils with difficulties more than subject teachers. Namely, during teaching, it is necessary to apply methods, procedures and tools in teaching, taking into account the individual needs, opportunities and ways of learning of pupils with difficulties in an inclusive environment, especially with the transition of pupils from lower to higher grades. The results indicate that 
differentiated and individualized planning requires teachers to set more optimal and customized tasks for pupils during the teaching process and to predict how and how much pupils will be burdened with certain content and activities, especially pupils at higher grades of primary school where the content is more extensive and the different demands on pupils alternate much more rapidly. Therefore, it is important to determine how much and what kind of support teachers need to provide (differentiated) and when (individualized) in order for pupils with difficulties to be successful in learning which shows the importance of the connection between teaching (by teachers) and learning (by pupils). If planning and assessment for learning adaptations is inadequate and if it does not provide information to pupils who need it, especially pupils with difficulties, on how to succeed in achieving important goals and educational outcomes, the learning environment will be uncertain and inadequate because the challenges of learning and support in teaching are out of balance. If teaching is not suited to the educational needs of pupils with difficulties in terms of planning, readiness, organization, according to the interest and learning styles of pupils, pupils will not be able to actively participate in teaching activities with other pupils, nor be able to independently perform educational demands. The results of this research indicate an insufficient number of teachers in schools with the necessary competencies for teaching pupils with difficulties and the need to acquire additional competencies, especially for higher grades in primary schools of the Republic of Croatia. From the above arises the need to acquire specific competencies of the 21st century in the system of inclusive education, as well as to set the standards needed for differentiated and individualized teaching.

\section{Conclusion}

The results show that in all items there is a statistically significant difference between class teachers and subject teachers in assessing frequency of their planning and application of methods for the successful implementation of activities in differentiated teaching and individualized approach to pupils with difficulties, which confirms the hypothesis. Namely, the results show that subject teachers self-assess that less than class teachers self-assess their planning and application of such methods which indicates the need to strengthen the professional competencies of teachers to provide support and modern teaching of pupils with difficulties, especially subject teachers. The way pupils and their teachers experience the learning and teaching environment in inclusive education profoundly shapes how pupils participate in teaching and how their teachers differentiate and individualize teaching. However, there are other elements which greatly affect the nature of the learning environment (for example, curriculum). Also, the association between teachers age, gender work experience and method 
use for individual approach was not examined on this occasion, which may be a limitation when interpreting the data due to their possible influence. Also a limitation may be that the applied questionnaire wasn't weighted and hasn't an adjustment for the participants.

The contribution of the results of this research is that they undoubtedly show that there are many teachers, especially teachers in lower grades applying inclusive practice, who can meet the educational needs of pupils with difficulties. However, the results suggest that teachers need to develop the differentiated and individualized teaching competencies needed to implement such practices that, in addition to adapting the environment, content, instruction, optimal time and tasks.

\section{References}

Ahon Adaka, T. (2013). Preparing Teachers for Inclusion: Models and Strategies. In M. Chitiyo, L. Aylward, E. Dalton, G. Prater, G. Chitiyo, A. Hughes (Eds.), The Bridge from Segregation to Inclusion. A Long Journey (9-10). Proceedings for the Thirteenth Biennial Conference of the International Association of Special Education Vancouver, British Columbia, Canada.

Bondie, R.S., Dahnke, C., \& Zusho, A. (2019). How Does Changing “One-Size-Fits-All” to Differentiated Instruction Affect Teaching? Review of Research in Education, 43(1), 336-362. DOI: https://doi.org/10.3102/0091732X18821130

Buli-Holmberg, J. (2008). Teachers role in Inclusive education. In H. Bjørnstud, \& S. Nilsen, (Eds.), Adapted Education - intension and school development. Oslo: Gyldendal Akademisk.

Buli-Holmberg, J., \& Jeyaprathaban, S. (2016). Effective practice in inclusive and special needs education. International journal of special education, 31(1), 119-134.

Conderman, G., \& Johnston-Rodriguez, S. (2009). Beginning teachers' views of their collaborative roles. Preventing School Failure, 53, 235-242.

Grimes, K.J., \& Stevens, D.D. (2009). Glass, bug, mud. Phi Delta Kappan, 90(9), 677-680.

Jenkins, J., Schiller, E., Blackorby, J., Thayer, S., \& Tilly, W. (2013). Responsiveness to intervention in reading: Architecture and practices. Learning Disability Quarterly, 36(1), 36-46.

Kudek Mirošević, J., \& Bukvić, Z. (2017). Differences in the provision of individualised educational support to students in different grades. Hrvatska revija za rehabilitacijska istraživanja, 53 (Supplement), 265-277.

Obiakor, F.E., Harris, M., Mutua, K., Rotatori, A., \& Algozzine, B. (2012). Making inclusion work in general education classrooms. Education and Treatment of Children, 35(3), 477-490.

Rock, M.L., Gregg, M., Ellis, E., \& Gable, R. A. (2008). REACH: A framework for differentiating classroom instruction. Preventing School Failure, 52(2), 31-47.

Schleicher, A. (2016). Teaching Excellence Through Professional Learning and Policy Reform: Lessons from Around the World. Paris: International Summit on the Teaching Profession; OECD Publishing.

Scruggs, T.E., Mastropieri, M.A., \& Marshak, L. (2012). Peer-mediated instruction in inclusive secondary social studies learning: Direct and indirect learning effects. Learning 
Disabilities Research \& Practice, 27(1), 12-20. DOI: https://doi.org/10.1111/j.15405826.2011.00346.x

Smale-Jacobse, A.E., Meijer, A., Helms-Lorenz, M., \& Maulana, R. (2019). Differentiated Instruction in Secondary Education: A Systematic Review of Research Evidence. Frontiers in psychology, 10, 2366. DOI: https://doi.org/10.3389/fpsyg.2019.02366

Subban, P. (2006). Differentiated instruction: A research basis. International Education Journal, 7(7), 935-947.

Thousand, J.S., Villa, R.A., \& Nevin, A.I. (2007). Differentiating instruction: Collaborative planning and teaching for universally designed learning. Thousand Oaks, CA: Corwin Press.

Tomlinson, C.A. (2000). Differentiation of Instruction in the Elementary Grades. ERIC Digest. Washington, D.C.: ERIC Clearinghouse on Elementary and Early Childhood Education.

Tomlinson, C.A. (2001). How to differentiate instruction in mixed-ability classrooms (2nd ed.) Alexandria, VA: Association for Supervision and Curriculum Development.

Tomlinson, C.A. (2004). Fulfilling the promise of the differentiated classroom: Tools and strategies for responsive teaching. Alexandria, VA: Association for Supervision and Curriculum Development.

Tomlinson, C.A. (2015). Teaching for Excellence in Academically Diverse Classrooms. Society 52(3), 203-209.

Tomlinson, C.A., \& Allan, S.D. (2000). Leadership for differentiating schools \& classrooms. Alexandria, VA: Association for Supervision and Curriculum Development.

Van Casteren, W., Bendig-Jacobs, J., Wartenbergh-Cras, F., Van Essen, M., \& Kurver, B. (2017). Differentiëren en Differentiatievaardigheden in Het Voortgezet Onderwijs. Nijmegen: Research Ned. 